Telecommuting Adaptation in Malaysia: Demographics, Beliefs, and Practices

\begin{tabular}{|c|c|}
\hline \multicolumn{2}{|c|}{$\begin{array}{l}\text { Ma, Guoxin }{ }^{1} \text {, Hen, Kai Wah' }{ }^{2} \text {, Chooi, Tsui Fei }{ }^{\mathbf{3}} \\
{ }_{1,2,3} \text { Universiti Tunku Abdul Rahman, Malaysia }\end{array}$} \\
\hline ARTICLE INFO & ABSTRACT \\
\hline Article history: & $\begin{array}{l}\text { By surveying } 201 \text { telecommuters in Klang Valley, the study examines } \\
\text { the employees' profiles, beliefs, and practices regarding the adoption }\end{array}$ \\
\hline Received: January 2, 2019 & of telecommuting in Malaysia. While our findings seem generally in \\
\hline Revised: February 28, 2019 & line with the existing literature in the western context, we reason that \\
\hline Accepted: March 17, 2019 & the practice of telecommuting remains nascent in its forms and thus \\
\hline
\end{tabular}

Telecommuting,

Malaysia,

Employee Perceptions

\title{
Clonflict of Interest:
}

None

Funding:

None

Corresponding Author: Ma, Guoxin, Faculty of Accountancy and Management, Universiti Tunku Abdul Rahman, Malaysia. Email: maguoxin@utar.edu.my

(C) Ma, Guoxin, Hen, Kai Wah, Chooi, Tsui Fei

This is an open access article under the CC BY-SA 4.0 international license.

\section{Introduction}

Over the last decade, the increased international competition in the business world, propelled by the advancement of information technology (ICT) has led companies in adopting extended workdays and flexible work schedules to respond better to employees' needs (Wynarczyk, 2005). In response to the changed expectations about time of work and location, organisations these days have emerged from their traditional boundaries to become more "diverse", "networked" and "flexible" (Maruyama \& Susanne, 2012). This led to the emergence of the concept of "telecommuting". As illustrated in the study by Karia and Muhammad Hasmi (2005), the concept of telecommuting has been in practice way back in the 1950s. With the advent of portable modems and personal computers in 1970's, the concept of working from home rapidly grown from its modest beginning before achieving such unprecedented level today.

The concept of telecommuting is seen as an important notion in organisations and the nation as poor management of skilled professionals may result in high attrition rate and failure in retaining valued professionals in the country. In fact, with the progress of Internet in the business world, the flexible work arrangement has become more pivotal and popular among job seekers. It is noted that the scarcity of skill workers throughout the nation is also a critical issue that needs to be addressed by relevant agencies, regardless public or private organisations. This was supported by Teh, et al. (2013) that Malaysia needs a pool of skill workers in various expertise to weather the coming storms in an industrialised nation. In fact, the telecommuting concept is also an essential component to develop a conducive and competitive business environment. 
Telework researchers found that the notion of telework, organisational flexibility schemes and the discourse of "work-life balance" projects have gained prominence in public arenas and organisations to bring about positive impacts in employees' lives (Lal \& Dwivedi, 2010).

Accordingly, telecommuting has become an increasingly popular work arrangement worldwide such as United States, European Union countries and India (Stephen, et al., 2010; Lister, 2013: Raghunam, 2014: Picu, 2016), being argued to benefit communities, organisations, and employees (Holloway, 2007). The advancements of information communication technology (ICT) have made telecommuting more practical than ever, especially in the Malaysian context (Hamsa, et al., 1997; Kanyakumari, 2014). Not surprisingly, a great number of companies in Malaysia indicate their intentions to introduce telecommuting to their employees, indicating a growing trend of adopting the practice (Yee, 2014).

Notwithstanding, reviews on the telecommuting literature show that most of the research has been conducted in the Western contexts (e.g., Crandall \& Gao, 2005; Pinsonneault \& Boisvert, 2001). There is a dearth of research on telecommuting in Malaysia, which is still seen as relatively new in the employment contexts (Teh, et al., 2013). Since research decontextualisation may result in a lack of relevance to unfamiliar contexts (see Rousseau \& Fried, 2001), there is a need for indigenous studies in local contexts which may provide a window for theory developments and producing more contextually relevant evidence to guide local practices (see Tsui, 2004). Against this background, the present study contributes to the telecommuting literature by examining the telecommuters' demographic profiles, beliefs, and practices in Malaysia.

\section{Literature Review}

According to Offstein, Morwick and Koskinen (2010), telework allows organisations in securing the best talent throughout the world. It was found that talent was often times confined by geography in the traditional work environments. The quality of human capital and the work produced are often constrained by the supply of talents who are willing to reside in the vicinity of the physical office space. Hence, with the adoption of telecommuting, the issue on the scarcity of skill workers could be well tackled since the nature of this approach allows the workers to work from any location and any time of the day. In other words, the pool of talented recruits is exponential with telework (Offstein et al., 2010). In accordance with this reasoning, a study conducted by the Society for Human Resource Management suggested that there has been a great hike in the number of firms intending to offer telecommuting (Clifton, 2014). The growth in telecommuting appears to be popular in for-profit organisations, not-for-profit organisations, and government bodies (Lister, 2013).

Despite the growing importance of the telecommuting concept, reviews, and research over the last two decades have concluded that it is still ambiguous on whether telecommuting is beneficial or detrimental to its practitioners (Gajendran \& Harisson, 2007). The concept of telecommuting is still a relatively new concept among Malaysians. In fact, some scholars argue that there has only been a limited number of multinational organisations having adopted telework practices such as IBM, Prudential, Amway International, Motorola and Taxes instruments (Farzana, Lim \& Haider, 2013). The majority of studies related to telework were conducted in the western context, particularly in developed countries. As envisioned by the former Prime Minister of Malaysia, Tun Dr. Mahathir Mohammad, Malaysia aims to move toward an industrialised nation by year 2020. The scarcity of skill workers throughout the nation is also a critical issue that needs to be addressed by relevant agencies, regardless public or private organisations (Karia \& Muhammad Hasmi, 2005). Hence, acknowledging the changing trend of telecommuting and its impact on retaining talents, it is particularly pertinent and timely to examine the beliefs and practices regarding telecommuting in Malaysia.

Given the diverse definitions used in the field of telecommuting research (see Popuri \& Bhat 2003; Nilles, 1994; Fairweather \& Ellison; 1999), and the infancy stage of telecommuting in the Malaysian context (Huda, et al., 2006), we adopt a broad definition of telecommuting as 'an alternative work arrangement in which employees perform tasks elsewhere that are normally done in a primary or central workplace' (Gajendran \& Harrison, 2007 pg. 1525).

Since we are more interested in identifying the contextual (e.g., age and gender, etc.) and perceptual (perceived benefits and costs, etc.) profiles, beliefs, and practices of telecommuters, we focus our review on three aspects of the existing research, namely, who teleworks, why do individuals telework and how do they telework (Bailey $\&$ Kurland, 2002). Please note that we use telecommuting and telework interchangeable in the present paper.

While research evidence appears to vary from context to context, there is a general tendency of demographics to make a difference on the adoption of telecommuting (see Bailey \& Kurland, 2002; Haddon \& Brynin, 2005). In general, research indicates that males tend to occupy a significant portion of the population of telecommuters (Olszewski \& Mokhtarian, 1994; Luukinen, 1996). On the other hand, telecommuting seems to be more popular among part-time female workers (Cyber Dialogue Inc., 2000), attracting growing scholarly attention on women teleworkers in a variety of national contexts (e.g., Wilson \& Greenhill, 2004; Díaz, 2015; Yordanova, 2015) and their roles in the consumption of technology (Webster, 2014). The gender differences in the adoption of 
telecommuting are argued to relate to gender roles at home, relating also to the marriage life especially in the Malaysian context (Subramaniam, et al., 2015). In a similar vein, people have been found to be more likely to adopt telecommuting (Luukinen, 1996).

In general, people's motivation to telework is closely related to the perceived benefits and challenges associated with telecommuting, which in turn depends on the mode of teleworking (Kurland \& Bailey, 1999). In other words, why do individual choose to telework is in close relation to their preferred telework methods. According to Kurland and Bailey (1999), home-based telecommuting generates the most benefits, including greater productivity, regulation compliance, level of morale and openness, while reducing interruption, turnover, absenteeism, and fixed costs. It also enables employees to gain a better work-life balance which in turn improve the work productivity (Tredup, 2016). However, it also creates the most challenges, such as in terms of performance monitoring, management, and control as well as difficulties in communication and personal interactions (Kurland \& Bailey, 1999). At the same time, Lipman (2015) lamented that remote works created lack of personal contact and slow responses between managers and telecommuters. A majority of other forms of telecommuting, such as satellite office, mobile work, and centre-based telecommuting, etc., have similar benefits and challenges (see, Mokhtarian, 1991; Kurland \& Bailey, 1999; Peters, et al., 2004). Given the scarce empirical research on telecommuting in Malaysia, this study aims to explore the contextual profiles of Malaysian telecommuters by asking three related research questions:

1) What is the demographic profile of telecommuters in Malaysia?

2) How do they telework?

3) What are their beliefs about the benefits and challenges regarding their adoptions of telecommuting?

To narrow down our research to a more manageable scope, we chose the small and medium enterprises (SMEs) in Malaysia as the research context. The detailed methods adopted by this study are explained next.

\section{Method}

We adopt a quantitative approach for this study and collected data surveying 221 telecommuters working in SMEs in Klang Valley, retaining a response rate of 32.9 percent. To qualify as a sample for this study, the respondent needed to fulfil an inclusion criterion of being a Malaysian adult (above 18 years old) who has at least three months of telecommuting experience. We defined SMEs according to the criteria laid out in the Guideline for New SME Definition (SME Corp Malaysia, 2013).

To contextualise survey instruments (Tsui, 2004) in Malaysia, we used an abductive approach to design the questionnaire by combining the existing literature and expert telecommuters's comments. In the questionnaire, we included three types of demographics (i.e., age, gender, and marital status) and four questions regarding how they teleworked (i.e., the duration, frequency and forms of telecommuting and time to commute). Seven types of technologies were included in the questionnaire to survey the popularity of different ICT in telecommuting, along with four respective items used to measure perceived benefits (i.e., job satisfaction, job productivity, job flexibility, time and cost saving) and challenges of telecommuting (i.e., impaired feeling of belongingness, impeded career development, loss of synergy and high need of self-discipline). Given the nature of these items, responses were measured on a Likert scale (1 represents extremely disagree; 5 represents extremely agree).

In validating measures used in this research, we carried out a preliminary study. Statistic testing of the data collected from the preliminary and subsequent main study ( $\mathrm{N}=206$ after excluding 15 incomplete responses from the total of 221 questionnaires collected) indicated an acceptable reliability of the measurement (i.e., $\alpha$ values of all items were above 0.7 ). We conducted descriptive data analyses of the data and will discuss our results in the next section.

\section{Results and Discussion}

Among the complete 206 questionnaires that we collected, we found $62 \%$ of the telecommuters were male $(n=127)$, almost twice of the female telecommuters who form only $38 \%$ of the sample $(n=79)$. In consistence with the literature (see Bailey \& Kurland, 2002), younger and/or married telecommuters were found to be more popular in Malaysia. The majority of the surveyed telecommuters aged between 26 and 45 ( $82.9 \%$; $n=174)$, while $73.1 \%$ of them were married ( $\mathrm{n}=147)$. There are two predominant views to explain the gender differences in telecommuting. The first perspective focuses on issues around work-life balance and boundary (e.g., Díaz, 2015; Holloway, 2007; Clark et al., 2015), while the second stream of research looks at gender and telecommuting in terms of gender roles and identity (e.g., Beasley, et al., 2001; Wilson \& Greenhill, 2004; Bryson, et al., 2014). Research further suggests that both perspectives on gender and telecommuting relate to the telecommuters' levels of independency from family roles, implying that their marital status may have significant influence on their adaptation of telework (e.g., Dettling, 2016; Sharmeen, et al., 2014). Recent empirical evidence how's that the relationships between gender, marriage life, family roles and the adaptation 
of telecommuting are especially relevant in the Malaysian context (e.g., Subramaniam, et al., 2015). Overall, our results indicate profiles in line with the existing research evidence. With reference to the growing interest on telework and work-life balance in the Malaysian context (e.g., Othman, et al., 2009) and research evidence to indicate that work-life conflicts manifest differently in the West and East (e.g., Hassan, et al., 2010), our findings indicate a need for further research on the roles of women in telecommuting, and their work perceptions and expectations, in the Malaysian employment context. This is especially relevant since the preliminary empirical evidence suggests that women in the western and eastern contexts may have different preferences with regard to telecommuting (Adya, 2008).

The trend of telecommuting adoption is expected to evolve among SMEs since various studies have documented the growth of telework and how it benefits both employers and their employees. This was supported by ample evidence that the gender classification, particularly the female gender is capable to develop their full labour market potential to contribute significant macroeconomic gains (Clements, Elborgh-Woytek, Fabrizio, Kochhar, Kpodar, Newik, Schwarts \& Wingender, 2013). It is forecasted that the statistics for both the male and female gender on the adoption of telecommuting in the near future would increase gradually. Premised on the above, the results above answers Research Objective 1 and Research Question 1 where there is no significant differences between the socio-demographic factor on gender and the intention to telecommute.

Secondly, our analyses show that Malaysians tended to prefer telecommuting when they had to take longer time to travel to work, with $72 \%$ of the respondents $(n=148)$ would have to travel for over half an hour to work. Similarly, $72 \%$ of the participants telecommuted frequently (at least three times a week), forming the vast majority of the telecommuters. Slightly over half of the telecommuters (51\%) had used telecommuting to work for over 4 years, suggesting that the practice of telecommuting has been in place in the Malaysian employment context for a reasonable period of time. In terms of forms of telecommuting, the majority of the participants $(60 \%)$ indicated their experience with home-based telecommuting and working at client's location (35\%), while the rest (about 5\%) adopted other forms of telecommuting (e.g., telework centre). These analyses suggest that telecommuting is still in quite nascent forms in the Malaysian context, despite the seemingly long-existence in the country. This is somewhat surprising since the practice of telecommuting was introduced, and has been studied, quite a while ago (e.g., Hamsa, et al., 1997). Yet, our findings suggest that the telecommuting practices remain quite basic in Malaysia, with most of our respondents engaged in home-based telecommuting. Accordingly, although the home-based telework has attracted some scholarly attention (e.g., Heng, et al., 2012), there is an urgent need to study the feasibility and potential effectiveness of other forms of telecommuting in Malaysia (see Kurland \& Bailey, 1999; Peters, et al., 2004).

Finally, broadband and notebook were perceived to be the most popular and important tools for telecommuting in Malaysia $(\overline{\mathrm{x}}=4.41$ and 4.17 , respectively on a scale of $5 ; \mathrm{n}=206)$, followed by mobile phone $(\overline{\mathrm{x}}=3.88)$, remote access $(\overline{\mathrm{x}}=3.00)$, desktop $(\overline{\mathrm{x}}=2.88)$, dedicated phone line $(\overline{\mathrm{x}}=2.56)$ and dialup internet $(\overline{\mathrm{x}}=1.63)$. Following on from this, both perspectives also explain why people prefer to telework. Research suggests that telecommuting helps employees to manage a better work life balance by allowing them to work more flexibly and manage time more productively according to their own preferred routines (Díaz, 2015).

We found job satisfaction and job flexibility to be the most important benefits for the Malaysian telecommuters $(\overline{\mathrm{x}}=4.0$ and 3.9, respectively), followed by time and cost saving and job productivity $(\overline{\mathrm{x}}=3.80$ and 3.79 , respectively). Similarly, impeded career development and loss of synergy satisfaction were believed to be the most significant challenges for telecommuting $(\overline{\mathrm{x}}=3.30$ and 3.28 , respectively), followed by high need for self-discipline and impaired feeling of belongingness $(\overline{\mathrm{x}}=3.12$ and 2.89 , respectively). These findings are generally in line with the existing literature (Kurland \& Bailey, 1999; Peters, et al., 2004). These results indicate that the motivational mechanisms of telecommuting are likely to be comparable between the West and the East.

\section{Future Research}

While our findings appear to be mostly in line with the existing literature, especially in terms of the perceived benefits and challenges for telecommuting, some results are not consistent with the findings in the Western context. For example, while telecommuters in the USA tend to be more equal in gender (Cyber Dialogue Inc., 2000), we found telecommuting seemed to be more popular among Malaysian males. Previous studies have found that the classification of gender does not have significant association with the adoption of telecommuting. For example, Russell's (2012) study on workplace isolation and gender among teleworkers indicated that gender was statistically insignificant to telework practices. Another earlier study by Peter, Tijdens and Wetzels (2001) also concluded that the difference of gender did not have much impact on the adoption of telecommuting. Contrary to our findings, Fondaz (2013) found that women are more likely to telecommute while men are more likely to use flexible working hours, a similar conclusion as to Aboelmaged and Elamin (2009). While this gender difference may simply reflect the nature of the work (Bailey \& Kurland, 2002), further studies looking into the relationships between gender identities, family roles and telecommuting in 
Malaysia may be fruitful, especially in light of the recently emerging literature on women teleworkers in Malaysia (Karia \& Asaari, 2003).

Furthermore, we found the forms of telecommuting in Malaysia remain basic and relatively unsophisticated, compared to the West (e.g., Peters, et al., 2004). According to Richard (2012), substantial amount of planning is required to ensure a successful telecommuting approach. The said planning includes proper training, technical support technology selection, budget management and cost. Richard (2012) added that a welldeveloped telecommuting program strategy includes technological infrastructure support and network support.

Besides given the right tools, telecommuters would be able to work independently should the infrastructure be fitted well to accommodate the job requirements. Cross (2014) postulated that facilities and design of a work environment have significant influences on employees and their productivity accordingly. To a certain extent, proper management and advanced technology may facilitate the adoption of telecommuting in a firm. Before initiating a telecommuting program, firms' internal communications facilities, resources, and necessary funding such as hardware and software arrangements are essential to facilitate the adoption and proper implementation of the concept. In addition, suitable work setting such as ergonomic furniture that is functional, adaptable, and aesthetic in appearance is another essential facilitating condition to telecommute.

In fact, sufficient amount of tools and space was also found to be important contributors for an effective workat-home project. In a similar vein, Watad and Disanzo (2000) has also pointed out that it is equally pertinent to deploy reliable, new information technology architecture to ensure a successful adoption of the telecommuting concept. This includes installing hardware and software resources, expanding architecture, which includes remote access and provide solutions to security concerns. Therefore, while our finding that telecommunication practices being still basic and unsophisticated may be due to cultural, structural and/or infrastructural indigenousness of the Malaysian context, the trend may as well be of a managerial nature, i.e., there may be less managerial resources and capabilities, especially at the strategic levels, to put telecommuting into more advanced and sophisticated practices in Malaysia. This direction is worthy of further research, to examine the relationships between the local contexts and the practice of telecommuting and to further investigate the reasons behind the lagging telecommuting practices in Malaysia.

Especially, our findings make a contribution to the understanding of telecommuting arrangements in the SMEs sector. While previous research argues that telecommuting in Malaysian SMEs may encounter several technology related difficulties and thus the practice of telecommuting is still low compared to developed countries (e, g., Kodukula, 2011), the recent literature suggests that SMEs in Malaysia nowadays tend to be more adaptive to technological advancements (Omar, 2010; Zailani, et al., 2009). There is a promising area of research to study telecommuting in the SMEs in Malaysia in the future.

\section{Conclusion}

The present study provides straightforward and helpful insights into the practice and beliefs among telecommuters in the Malaysian context. In answering the research questions, we collected valid quantitative data from 201 telecommuters in Malaysia and identified both similarities and differences between telecommuting in Malaysia and the West. Overall, this study suggests that the concept of telecommuting is both relevant and helpful as an alternative work arrangement in Malaysia, but its practices remain nascent and thus this phenomenon requires more research in the local contexts.

References

Aboelmaged, M. G., \& Elamin, A. M. (2009). Teleworking in United Arab Emirates (UAE): An impriical study of influencing factors, facilitators, and inhibitors. International Junral of Business Science and Applied Management, 4(1), 19-35.

Adya, M. P. (2008). Women at work: Differences in IT career experiences and perceptions between South Asian and American women. Human Resource Management, 47(3), 601-635.

Bailey, D., \& Kurland, N. (2002). A review of telework research: Findings, new directions, and lessons for the study of modern work. Journal of Organisational Behaviour, 383 - 400.

Beasley, R. E., Lomo-David, E., \& Seubert, V. R. (2001). Telework and gender: implications or the management of information technology professionals. Industrial Management \& Data Systems, 101(9), 477-482.

Bryson, J., Wilson, J., Plimmer, G., Blumenfeld, S., Donnelly, N., Ku, B., \& Ryan, B. (2014). Women workers: caring, sharing, enjoying their work-or just another gender stereotype Labour \& Industry: a journal of the social and economic relations of work, 24(4), 258-271.

Clifton, J. (2014, March 18). Gallup: The Truth About Telecommuting. Retrieved from: https://www.linkedin.com/today/post/article/20140318142538-14634910-gallup-the-truth-abouttelecommuting; accessed on June 2, 2014. 
Crandall, W. \& Gao, L. (2005). An update on telecommuting: Review and prospects for Emerging issues. $S A M$ Advanced Management Journal, 70(3), 30.

Cross, T. (2014). Telecommuting 2014: The Future Technology of Working Green. Retrieved November 1, 2014, from Techtionary: http://techtionary.com/books/telecommuting/index.pdf.

Cyber Dialogue Inc. (2000). Small Business/Home Office Trend Report: New York.

Díaz, V. L. (2015). Telework as a way to balance work and family life: good practices in Argentina. Work-Life Balance and the Economic Crisis: Some Insights from the Perspective of Comparative Law (Volume I: The Spanish Scenario), 258.

Fairweather \& Ellison, N. (1999). Surveillance in employment: The case of teleworking. Journal of Business Ethics, 22(1), 39-49.

Farzana, Q., Lim, C., \& Haider, M. A. (2013). Malaysian Employees' Perception Pertaining to Telework. Business and Management Quarterly Review, 4(1), 63-76.

Fondaz, N. (2013, July 19). The Atlantic. Retrieved November 1, 2014, from How Women and Men Use Flexible Work Policies Differentl: http://www.theatlantic.com/sexes/archive/2013/07/how-womenand-men-use-flexible-work-policies-differently/277954/

Gajendran, R., \& Harisson, D. (2007). The good, the bad and the unknown about telecommuting: Meta-analysis of psychological mediators and individual consequences. Journal of Applied Psychology, 6(92), 1524-1541.

Haddon, L., \& Brynin, M. (2005). The character of telework and the characteristics of teleworkers. New Technology, Work and Employment, 20(1), 34-46.

Hamsa, A. A. K., Oniyirimba, L. C., \& Ahmad, S. (1997, January). An exploratory analysis of factors toward the emergence of teleworking in Malaysia. In System Sciences, 1997, Proceedings of the Thirtieth Hawaii International Conference on (Vol. 4, pp. 99-109). IEEE.

Hassan, Z., Dollard, M. F., \& Winefield, A. H. (2010). Work-family conflict in East vs Western countries. Cross Cultural Management: An International Journal, 17(1), 30-49.

Heng, T. B., San, O. T., \& Lee, L. Y. (2012). The acceptance and effectiveness of Telecommuting (work from home) in Malaysia. Asia Pacific Journal of Research in Business Management, 3(3).

Holloway, D. (2007). Gender, telework and the reconfiguration of the Australian family home. Continuum, 21(1), 33-44.

Huda, I., Juliana, W., Nafishah, O., Rafidah, A., Wan Rozaini, S., \& Zahurin, M. (2006). The Challenges of Telecommuting Implementation in Malaysia Government Offices. Sintok, Kedah: Idea Group Publishing.

Kanyakumari, D. (2014, February 26). Malaysia's population to number 30 million on Thursday. Retrieved from The Star Online: www.thestar.com.my; accessed on June 1, 2014.

Karia, N., \& Asaari, H. (2003). Determinants of Telework Implementation in Malaysian Organisations. International Business Information Management, 566-570.

Karia, N., Asaari, A. H., \& Hasmi, M. (2006). Telework and Women: Case of Women Workers in The Northern States of Malaysia. International Academy of Business and Technology Conference.

Karia, N., \& Muhammad Hasmi, A. (2005). Determinants of Telecommuting Among Women Workers in Penang: A Case Study. Penang, Malaysia: Universiti Sains Malaysia.

Kodukula, S. (2011). Systems Thinking and Practice for Telecommuting Issues. International Journal of Computer Applications, 29(8), 21-27.

Kurland, N., \& Bailey, D. (1999). Telework: The Advantages and Challenges of Working Here, There, Anywhere and Anytime. Journal of Organisational Dynamics, 53- 67.

Lal, B., \& Dwivedi, Y. (2010). Investigating homeworkers' inclination to remain connected to work at "anytime, anywhere" via mobile phones. Journal of Enterprise Information Management, 23(6), $759-774$.

Lipman, V. (2015). The Type B Manager: Leading Successfully a Type A World, New Jersey: Prentice Hall Press.

Lister, K. (2013). Global Workplace Analytics and the Telework Research Network. Retrieved from Global Workplace Analytics and the Telework Research Network:

http://www.globalworkplaceanalytics.com/telecommuting-statistics; accessed on May 2, 2014. 
Marican, S., Sabil, S., Zakaria, R. H., \& Ab Rahman, A. (2011). Can supportive management contribute to the well-being of Muslim working women in Malaysia? African Journal of Business Management, $5(12), 4883$.

Maruyama, T., \& Susanne, T. (2012). From anxiety to assurance: concerns and outcomes of telework. Personnel Review, 41, 450-469.

Mokhtarian, P. L. (1991). Telecommuting and travel: state of the practice, state of the art Transportation, 18(4), 319-342.

Nilles, J. M. (1994). Making telecommuting happen, Van Nostrand Reinhold. New York.

Offstein, E., Morwick, J., \& Koskinen, L. (2010). Making telework work: leading people and leveraging technology for competitive advantage. Strategic HR Review, Vol. 9, 32 - 37.

Olszewski, P., \& Mokhtarian, P. (1994). Telecommuting frequency and impacts for State of California employees. Technological Forecasting and Social Change, 45(3), 275-286.

Omar, R., \& Sapuan, D. A. (2010). Rejuvinating Motivations and Renewing Technology: A Quest for Electronic Endeavor among Malaysian SMEs. European Journal of Social Sciences, 2(3), 457-470.

Othman, N., Yusof, S. A. M., \& Osman, W. R. S. (2009). A conflict between professional vs. domestic life? Understanding the use of ICT in teleworking for balance in work and family units. Computer and Information Science, 2(2), 3.

Peters, P., Tijdens, K. G., \& Wetzels, C. (2004). Employees' opportunities, preferences, and practices in telecommuting adoption. Information \& Management, 41(4), 469-482.

Picu, C. G., \& Dinu, A. (2016). Research on the Current Telecommuting Trends in United States and European Union Markets. Management and Economics Review, 1(2), 194-202.

Pinsonneault, A., \& Boisvert, M. (2001). The impacts of telecommuting on organizations and individual: A review of the literature. In Telecommuting and virtual offices: Issues and opportunities (pp. 163185). IGI Global.

Opuri, Y. D. \& Bhat, C. R, (2003). On Modelling the Choice and Frequency of Home-Based Telecommuting. Retrieved February 25, 2014, from http://www.ltrc.lsu.edu/TRB 82/TRB2003-001314.pdf

Raghuram, S. (2014). Telecommuting in India: Pitfalls and Possibilities. South Asian journal of Human Resources Management, 1(2), 207-220.

Russell, D. G. (2012). An Investigation of The Relationship Between Workplace Isolation and Engagement Among Teleworkers, 2 - 66.

Rousseau, D. M., \& Fried, Y. (2001). Location, location, location: Contextualizing organizational research. Journal of organizational behavior, 22(1), 1-13.

Sharmeen, F., Arentze, T., \& Timmermans, H. (2014). An analysis of the dynamics of activity and travel needs in response to social network evolution and life. 13th WCTR, July 15-18, 2013 - Rio de Janerio, Brazil.

Stephen, D., Justin, J., \& Raymond, B. (2010, June). IDC Market Analysis Report. Retrieved from Worldwide Mobile Worker Population 2009- 2013 Forecast: http://www.gotomypc.com/remote access/images/pdf/How to Equip_Your_Company for the N ew_Mobile_Workforce.pdf; accessed on June 11, 2014.

Teh, B., Patrick, C., Loh, Y., Ong, T., \& Hong, Y. (2013). Enhancing the Implementation of Telecommuting in Malaysia. Asian Social Science, 9(7).

Tsui, A. S. (2004). Contributing to global management knowledge: A case for high quality indigenous research. Asia Pacific Journal of Management, 21(4), 491-513.

Tredup, H. F. (2016). Virtual: A Guide to Telecommuting, United States: Praca Print.

Tremblay, D. G. (2002). Balancing work and family with telework? Organizational issues and challenges for women and managers. Women in Management Review, 17(3/4), 157-170.

Watad, M. M., \& Disanzo, J. F. (2000, January 15). MIT Sloan Management Review. Retrieved November 3, 2014, from The Synergism of Telecommuting and Office Automation: http://sloanreview.mit.edu/article/the-synergism-of-telecommuting-and-office-automation/

Webster, J. (2014). Shaping women's work: Gender, employment, and information technology (London: Longman). 
Wilson, M., \& Greenhill, A. (2004). Gender and teleworking identities in the risk society: a research agenda. New Technology, Work and Employment, 19(3), 207-221.

Wright, K. B. (2015). 20 Workplace relationships: Telework, work-life balance, social support, negative features, and individual/organizational outcomes. Communication and Technology, 5, 397.

Wynarczyk, P. (2005). The impact of Connectivity technologies on e-flexible working practices of small and medium-sized enterprises in the Northeast of England. New Technology, Work and Employment, 20(3), 234-247.

Yee, M. K. (2014, March 7). It's Unclearly Defined, but Telecommuting is on the Rise. Retrieved April 21, 2014, from The New York Times: http://www.nytimes.com/2014/03/08/your-money/whenworking-in-your-pajamas-is-more-productive.html?_r=0

Yordanova, G. (2015). Global Digital Workplace as an Opportunity for Bulgarian Woman to Achieve WorkFamily Balance. The Dynamics of Virtual Work. Working paper 5.

Zailani, S., Dahlan, N., \& Jallaludin, Y. H. (2009). E-business adoption among SMEs in Malaysia: Investigation from the supply chain perspective. Journal of Problems and Perspectives in Management, 7(4), 46-57. 